\title{
An application of Six Sigma DMAIC methodology in outsourcing management process improvement
}

\author{
Mohsen Cheshmberah $^{\mathrm{a}^{*}}$ and Seyed Mohammad Mehdi Nabavi ${ }^{\mathrm{b}}$
}

${ }^{a}$ Department of Management, Malek Ashtar University of Technology, Tehran, Iran

aAndishe-varzan Tamin Kavosh (ATAK) research group, Tehran, Iran

\section{H R O N I C L E \\ A B S T R A C T}

Article history:

Received December 10, 2013

Received in revised format

16 March 2014

Accepted May 202014

Available online

May 232014

Keywords:

DMAIC

Six Sigma

Outsourcing

Improvement project
Outsourcing is a common practice among the organizations and it is a major element in business strategy. It has recognized as an area of strategic importance. This article represents the application of the DMAIC Six Sigma approach to improve outsourcing management process with an emphasis to reduce delay of delivery time for a manufacturing company. The paper identifies each stage of the DMAIC cycle and the Six Sigma tools that were applied. The improvement project has been implemented in seven months.

\section{Introduction}

Outsourcing is a common practice among the organizations as well as a major element in business strategy (Kremic et al., 2006) and it has become an interesting area of strategic planning (Jennings, 1997; Cheshmberah, et al. 2011). Clearly, for outsourcing management, an efficient process is necessary and must be continuously monitored and improved in any organization. This paper describes the activities of definition, implementation and improvement of project based using Six Sigma technique. The study uses DMAIC methodology (an abbreviation for Define, Measure, Analyze, Improve and Control) to improve the process of outsourcing management in a mediumsized manufacturing organization. Six sigma is a systematic and data-driven approach and according to statistical terms, it means 3.4 defects per million opportunities (Kwak \& Anbari, 2006; Ho et al., 2008). A Six Sigma defect is described as anything outside of customer specifications and a it provides an opportunity of the total quantity of chances for a defect. The objective of the Six Sigma methodology is the process improvement and variation reduction through the application of Six Sigma improvement projects. Table 1 shows details of the DMAIC methodology.

* Corresponding author

E-mail address: mcheshmberah66@gmail.com (M. Cheshmberah)

(C) 2014 Growing Science Ltd. All rights reserved.

doi: $10.5267 /$ j.uscm.2014.5.006 
Table 1

Key steps of DMAIC process (Kwak \& Anbari, 2006)

\begin{tabular}{|c|c|}
\hline steps & Major activities \\
\hline Define & $\begin{array}{l}\text { Define the requirements and expectations of the customer, the project boundaries, the process by mapping the } \\
\text { business flow (such as SIPOC) }\end{array}$ \\
\hline Measure & $\begin{array}{l}\text { Measure the process to satisfy customer's needs, develop a data collection plan and collect and compare data } \\
\text { to determine issues and shortfalls }\end{array}$ \\
\hline Analyze & $\begin{array}{l}\text { Analyze the causes of defects and sources of variation, determine the variations in the process and prioritize } \\
\text { opportunities for future improvement }\end{array}$ \\
\hline Improve & Improve the process to eliminate variations and develop creative alternatives and implement enhanced plan \\
\hline Control & $\begin{array}{l}\text { Control process variations to meet customer requirements, develop a strategy to monitor and control the } \\
\text { improved process and implement the improvements of systems and structures }\end{array}$ \\
\hline
\end{tabular}

The methodology is believed to be introduced in a US firm, where first, a team at Motorola developed a process with four-phase "Definition" "Analysis" "Optimization" and "Control" for improving the products quality. Based on this four-phase process, two methodologies of Six Sigma were developed: DMAIC (Define, Measure, Analysis, Improve, and Control) (Table 1), and DMADV (Define, Measure, Analysis, Design, and Verify).

The DMAIC process was developed to eliminate defects in production or service processes (Ho et al., 2008). The DMAIC cycle maintains many similarities with Deming's cycle "Plan-Do-Check-Act" (PDCA) and places more emphasis on integrating specific tools into each step of the method (Schroeder et al., 2008; Kumar et al., 2008).

\section{Problem statement}

In any organization, outsourcing management has its own processes and activities and this process may be varied in various organizations. Therefore, to improve outsourcing management process, the characteristics of each organization should be considered. In this case study, outsourcing management process was analyzed in a manufacturing company in the aerospace industry and several improvement opportunities were identified in various areas such as "product quality", "delivery time" and "products cost price". According to the importance of customer satisfaction and due to the high frequency of their complaints on delay time, reducing the delay of lead-time in the customer orders, were considered. After this decision, the improvement project team was formed and managing director of studied organization was chosen as the project administrator and the head of the project team. After the team formation, the project charter was developed and as covenant (agreement) between the project administrator and the project champion was signed.

This paper describes the methodology of the improvement project and its activities of definition and implementation. In addition to improvement of the outsourcing management process, practice in team working, enhancing creativity and the power of idea making and changing in managerial mental paradigms are other outcomes of this project implementation.

\section{Definition phase}

In this phase, objective(s) and scope of the project are defined and information of process and customer(s) are gathered. Activities of this phase are "titling the project", "problem statement", and "drawing CTQ tree. Moreover, the names of the champion, team members, supervisors and consultants, the project scope, the project objective, scheduling and Gantt chart, financial/nonfinancial benefits and outcomes, required resources, SIPOC diagram, and VOC table are other items of definition phase. 


\subsection{Project Description}

Considering that great deal of operations of the company are outsourced to outside suppliers, an important source of delay is "long time" of outsourcing process. In practice, it is possible to divide the process into two sections, (1) the company and (2) the suppliers. Therefore, it is expected that through some improvements, less delivery time is achievable.

\subsection{Business case}

The objective of this improvement project is to lessen the delivery delay and to increase the customers' satisfaction.

\subsection{Project goal}

The primary objective of the project is to address delivery delay expressed in three sub-objectives: reducing the average time of contract negotiations up to $20 \%$, reducing suppliers' delay up to $15 \%$ and lessening the average delivery time up to $20 \%$.

\subsection{Other expected results}

Higher customers' satisfaction, increased capacity, selecting proper suppliers, and providing appropriate decision-making conditions are some of other expected results of the project.

\subsection{Required financial resources}

Based on the estimations, costs include training courses for suppliers, project team transportation for information gathering, and implementing workshops.

\subsection{Project schedule}

It was estimated that the project takes 6 months, and schedule was codified based on the activities of the 5 phases of DMAIC methodology through a Gantt chart.

\subsection{Project structure}

Due to the importance of senior manager's commitment, he undertook the role of "champion". In addition, to facilitate project implementation, the "production manager" was chosen as the "project manager" and was commissioned to choose the team members. After the formation of the project team, "quality manager", "financial manager" and a master black belt were chosen as "quality supervisor", "financial supervisor" and "the project consultant". Fig. 1 illustrates the project structure.

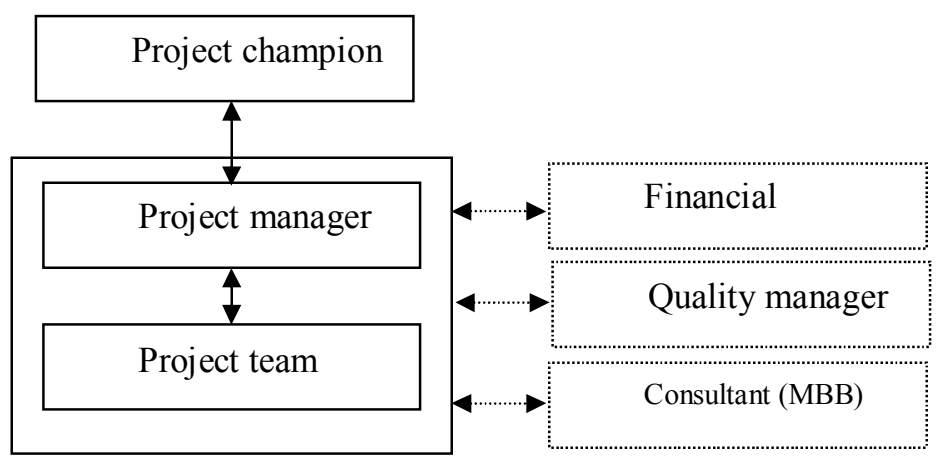

Fig. 1. Project structure 


\subsection{SIPOC Diagram}

SIPOC is a general diagram of process and provides a general view of suppliers, inputs, processes, outputs and customers. This represents a flow diagram and is implemented to define and examine an operation from the supplier to the customer (Basu \& Wright, 2003). SIPOC ensures that all project team members have a common perception of the process. Moreover, it helps the champion to see which scope that is being worked on. In fact, SIPOC is a tool for determining project scope. Table 2 illustrates the SIPOC of the outsourcing process.

Table 2

SIPOC diagram of the process

\begin{tabular}{|c|c|c|c|c|}
\hline Suppliers & Inputs & Process & Outputs & Customers \\
\hline \multirow{3}{*}{ Customers } & \multirow{3}{*}{ Orders } & $\begin{array}{c}\text { Receiving customer's } \\
\text { order }\end{array}$ & \multirow{3}{*}{ Final products } & \multirow{3}{*}{ Customers } \\
\hline & & $\begin{array}{l}\text { Contracting with the } \\
\text { customer }\end{array}$ & & \\
\hline & & $\begin{array}{l}\text { Dividing the order } \\
\text { between the project }\end{array}$ & & \\
\hline $\begin{array}{l}\text { Quality Dept. (QC } \\
\text { office) }\end{array}$ & $\begin{array}{l}\text { Blank forms of quality } \\
\text { control }\end{array}$ & \multirow{3}{*}{$\begin{array}{l}\text { Identifying, Evaluating } \\
\text { and selecting the } \\
\text { supplier(s) }\end{array}$} & $\begin{array}{l}\text { Supplier's qualitative } \\
\text { performance records }\end{array}$ & $\begin{array}{l}\text { Quality Dept. (quality } \\
\text { records office) }\end{array}$ \\
\hline Suppliers & $\begin{array}{l}\text { Filled forms of quality } \\
\text { control }\end{array}$ & & \multirow{4}{*}{ Technical problems report } & \multirow{4}{*}{ Engineering Dept. } \\
\hline $\begin{array}{l}\text { Quality Department } \\
\text { (monitoring office) }\end{array}$ & & & & \\
\hline Engineering Dept. & $\begin{array}{l}\text { Technical documents } \\
\text { (preliminary) }\end{array}$ & \multirow{2}{*}{$\begin{array}{l}\text { Signing the purchase } \\
\text { contract }\end{array}$} & & \\
\hline Project managers & Suppliers' information & & & \\
\hline \multirow{3}{*}{ Financial Dept. } & \multirow{3}{*}{ Financial resources (cash) } & \multirow{2}{*}{$\therefore----------\cdot$} & \multirow{3}{*}{ Manufacturing technology } & Project managers \\
\hline & & & & Suppliers \\
\hline & & $\begin{array}{l}\text { Monitoring, tracking and } \\
\text { control of supplier(s) }\end{array}$ & & Engineering Dept. \\
\hline Suppliers & Proposals & $\begin{array}{c}\text { Delivering products to } \\
\text { company' warehouse by } \\
\text { the supplier(s) }\end{array}$ & \multirow{3}{*}{$\begin{array}{l}\text { Quality control reports and } \\
\text { Alerts }\end{array}$} & Project managers \\
\hline \multirow{2}{*}{ Commercial Dept. } & Blank contract & \multirow{2}{*}{.-----------} & & \\
\hline & The Rules and regulations & & & Senior manager \\
\hline \multirow[b]{2}{*}{ Suppliers } & \multirow[b]{2}{*}{ Products (not inspected) } & $\begin{array}{l}\text { Browsing commitments to } \\
\text { the customers }\end{array}$ & \multirow[b]{2}{*}{$\begin{array}{l}\text { Suppliers's financial } \\
\text { performance records }\end{array}$} & Senior manager \\
\hline & & $\begin{array}{l}\text { Receiving the products } \\
\text { from the supplier(s), } \\
\text { preparing \& delivering to } \\
\text { the customer(s) }\end{array}$ & & Financial Dept. \\
\hline
\end{tabular}

\subsection{Voice of the Customer analysis}

Customer requirements should drive management systems development (and improvement). The purpose of specifications is to transmit the voice of the customers throughout the organization (Pyzdek, 2003). It is applied to clarify the customer's needs and understanding of the desired products or services. Table 3 shows the results of voice of the customers regarding the outsourcing process.

\subsection{Drawing Critical to Quality (CTQs) tree}

In Six Sigma, the customer Critical to Quality Factors (CTQ) play the key role to agree and to define critical quality factors as seen by customer. It is important that the customers' requirements are 
understood when defining the CTQs (Basu \& Wright, 2003). Figure 2 illustrates the CTQ tree of the outsourcing process. Considering that the senior manager has chosen CTQ of "delivery delay", it is detailed in a separate tree (Fig. 3). In addition, Table 4 shows the CTQs definitions, which are associated with defects definitions, and How to calculate the defect.

\section{Table 3}

The part of Voice of the Customer analysis

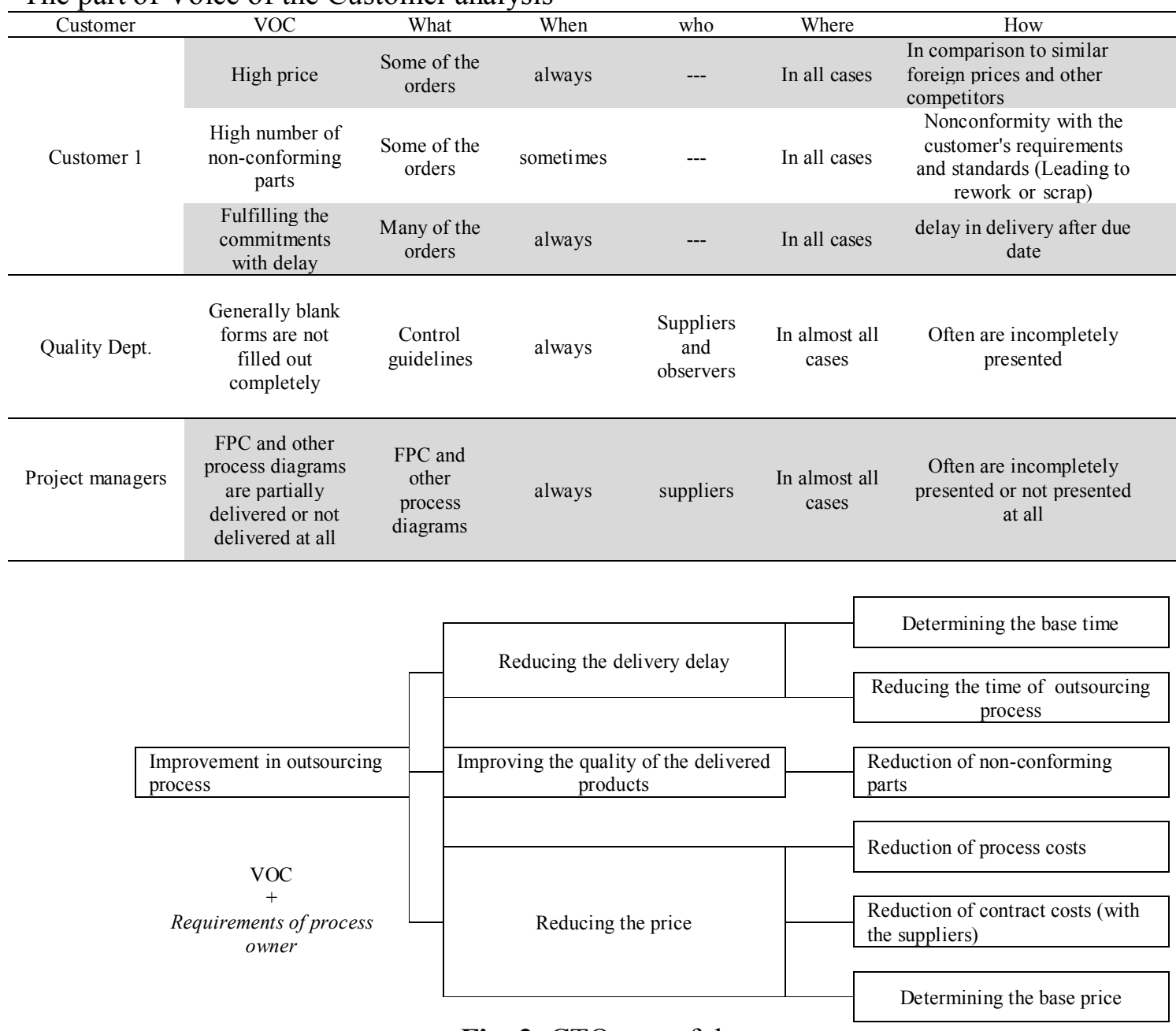

Fig. 2. CTQ tree of the process

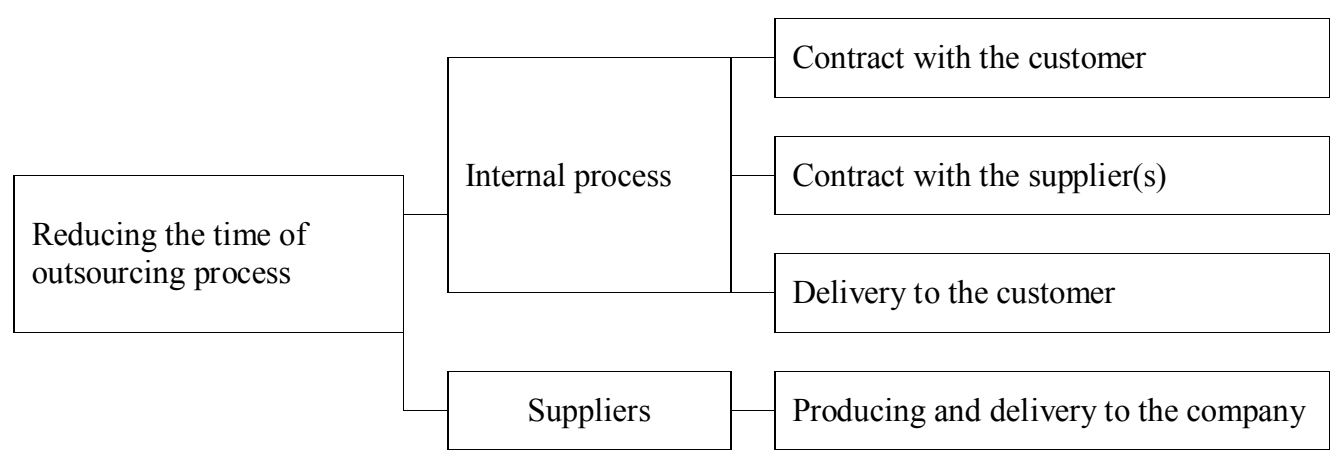

Fig. 3. Detailed CTQ of reducing the time of outsourcing process 
Table 4

The CTQs definitions, related defects definitions, and How to calculate the defect

\begin{tabular}{lcc}
\hline Process requirements (CTQ) & definition of the defect & How to calculate the defect \\
\hline $\begin{array}{l}\text { Reduction of the average time of } \\
\text { contracting }\end{array}$ & Up to 30 days & 30 minus real time of contracting \\
$\begin{array}{l}\text { Reduction of supplier delay } \\
\begin{array}{l}\text { Reduction of the average time of } \\
\text { delivery to the customer }\end{array}\end{array}$ & $\begin{array}{c}\text { Difference between "in the contract" and } \\
\text { "happened" delivery time }\end{array}$ & $\begin{array}{c}\text { "in the contract" delivery time } \\
\text { minus "happened" delivery time }\end{array}$ \\
\hline
\end{tabular}

\section{Measure Phase}

The primary objective of this phase is to specify the place and source of the problem by providing a realistic understanding of the problem and the process. Such insight helps us to limit the range of potential causes. The key elements of this phase include establishing a plan for data collection, analyzing variations and determining the level of Sigma performance (Basu \& Wright, 2003) (Pyzdek, 2003). Different steps of measure phase are as follows:

\section{Table 5}

FMEA table for the process

\begin{tabular}{|c|c|c|c|c|c|c|c|c|}
\hline 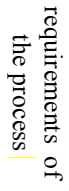 & 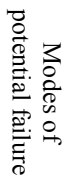 & 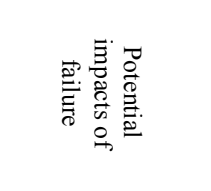 & 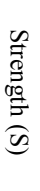 & 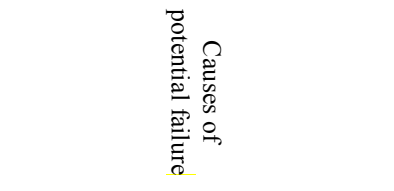 & 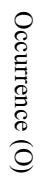 & 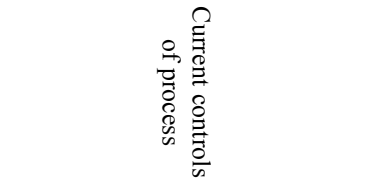 & 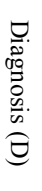 & Z \\
\hline \multirow{10}{*}{ 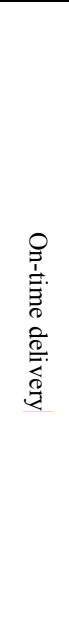 } & \multirow{10}{*}{ 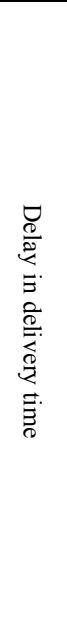 } & Increased price & 5 & $\begin{array}{l}\text { Weak assessment of staffs' } \\
\text { capacity }\end{array}$ & 10 & $\begin{array}{l}\text { Assignment sheets, project control } \\
\text { forms }\end{array}$ & 6 & 420 \\
\hline & & $\begin{array}{c}\text { Customer } \\
\text { dissatisfaction }\end{array}$ & 7 & Failing to assess suppliers' capacity & 10 & $\begin{array}{l}\text { Project manager's point of view, } \\
\text { evaluating suppliers }\end{array}$ & 6 & 420 \\
\hline & & & & $\begin{array}{l}\text { Technical weakness of the } \\
\text { suppliers }\end{array}$ & 10 & $\begin{array}{l}\text { Project manager's point of view, } \\
\text { evaluating suppliers }\end{array}$ & 6 & 420 \\
\hline & & $\begin{array}{l}\text { Reduction of } \\
\text { capacity }\end{array}$ & 6 & Insufficient identified suppliers & 8 & Suppliers' database & 7 & 392 \\
\hline & & & & $\begin{array}{l}\text { Lack of technical feasibility study } \\
\text { by suppliers }\end{array}$ & 10 & Request for quotation (RFQ) & 7 & 490 \\
\hline & & $\begin{array}{l}\text { Disruption in the } \\
\text { company planning }\end{array}$ & 6 & $\begin{array}{l}\text { Lack of capacity feasibility study } \\
\text { by suppliers }\end{array}$ & 10 & Project manager's point of view & 9 & 630 \\
\hline & & & & $\begin{array}{l}\text { Long geographical distance to the } \\
\text { suppliers }\end{array}$ & 9 & $\begin{array}{l}\text { Project control, Project manager's } \\
\text { point of view }\end{array}$ & 2 & 126 \\
\hline & & $\begin{array}{l}\text { Delay penalty (by } \\
\text { customers) }\end{array}$ & 3 & $\begin{array}{l}\text { Not having suitable environment } \\
\text { for accurate measurement }\end{array}$ & 2 & Project manager's point of view & 10 & 140 \\
\hline & & & & $\begin{array}{c}\text { Difficulty in providing accurate } \\
\text { measurement and special control } \\
\text { tools }\end{array}$ & 8 & Quality Dept. & 9 & 504 \\
\hline & & Reduction in sales & 6 & Lake of a base time & 9 & Project manager's point of view & 10 & 630 \\
\hline
\end{tabular}

Step 1- Conducting FMEA for the CTQ under study (outsourcing process time, which is divided into 3 independent CTQs): To calculate risk priority number for potential defect causes in order to facilitate the analysis phase and to have more concentration on potential causes with maximum RPN. In fact, using FMEA, data gathering activities focus on more critical input and process variables. For example, table 5 lists part of FMEA table about delay time.

Step 2- Defining sample for the study domain and calculating sigma level: considering that sale contracts generally include several "order rows"; Each "order row" contains specific lot size and order delivery time (for example, a sale contract contains over 300 "order row"). there are only a limited number of main contracts of sale over a period of 3 years. Therefore, a sale contract was chosen by champion and the project team. This contract was constituted of 177 separate "order row" (Table 6). 
Step 3- calculating sigma level of the process: this index was calculated as follows in table 6. Each "order row" has chosen as "failure unit".

Table 6

Calculation of sigma levels of three sub-processes

\begin{tabular}{|c|c|c|c|}
\hline \multirow{5}{*}{$\begin{array}{l}\text { Calculation of sigma level } \\
\text { of "contracting sub-process" }\end{array}$} & \multirow{5}{*}{ CTQ1 } & The number of potential failure opportunities & $177 \times 100=17700$ \\
\hline & & Total number of actual failure opportunities & 17700 \\
\hline & & Calculation of DPO & 1 \\
\hline & & Calculation of DPMO & $1,000,000$ \\
\hline & & Calculation of sigma level (by standard tables) & 0.0 \\
\hline \multirow{5}{*}{$\begin{array}{l}\text { Calculation of sigma level } \\
\text { of "supply sub-process" }\end{array}$} & \multirow{5}{*}{ CTQ2 } & The number of potential failure opportunities & $59 \times 100=5900$ \\
\hline & & Total number of actual failure opportunities & 2630 \\
\hline & & Calculation of DPO & 0.438333 \\
\hline & & Calculation of DPMO & 438333 \\
\hline & & Calculation of sigma level (by standard tables) & 1.6552 \\
\hline \multirow{5}{*}{$\begin{array}{l}\text { Calculation of sigma level } \\
\text { of "delivery sub-process" }\end{array}$} & \multirow{5}{*}{ CTQ3 } & The number of potential failure opportunities & $17 \times 100=1700$ \\
\hline & & Total number of actual failure opportunities & 1112 \\
\hline & & Calculation of DPO & 0.654117 \\
\hline & & Calculation of DPMO & 654117 \\
\hline & & Calculation of sigma level (by standard tables) & 1.12 \\
\hline
\end{tabular}

Step 4- Detailed drawing of the process based on breaking up to the three sub-processes: in order to have better chance of analyzing and according to the determined Sigma level for each sub-process, we need to plot the process in more details.

Step 5- Determining bottlenecks: it is essential in this section to define time bottlenecks discuss more in analysis phase. Considering the three separate CTQs (contracting sub-process, supply sub-process, and delivery sub process), it was decided to conduct separate sampling for each CTQ after gathering information about the sample wholesaler contract.

Moreover, according to the consultant (master black belt) and the team's decision 20 samples adopted for each CTQ. This was because there is no limitation to get more than 20 samples for CTQ1 (contracting) and CTQ2 (supply), while only 20 articles of delivery CTQ had been fulfilled. In other words, 20 random samples for CTQ1 and CTQ2 and all fulfilled delivery cases were chosen and time bottlenecks were determined based on the average period of samples.

\section{Analysis Phase}

The problem is investigated more thoroughly in this phase especially by studying time bottlenecks by utilizing proper tools, root causes of the problem are identified. In fact, having root causes identified, the conditions for presenting the appropriate solutions and preventing causes of the problem in the next phase (Improvement phase) are provided. Followings are different steps of the analysis phase:

Step 1- Holding brain storm meetings and utilizing cause and effect analysis tools (fish bone) and Pareto analysis for CTQ1 (contracting), and CTQ3 (delivery); because these two sub-processes are completely in the functional area of the company.

Step 2- Depicting flow-chart and value analyzing of each of the three sub-processes to have better distinction between "value added" and "non-value added" operations.

Step 3- Interviewing suppliers: four suppliers were chosen; of which two suppliers had the highest delivery delay and two ones had the lowest. This tool was particularly used for supply sub-process. Finally, conducting the mentioned steps, lead to determining the root causes of delay in all 3 subprocesses of contracting, supply and delivery. Table 7 lists the identified causes. 
Table 7

List of the identified root causes

\begin{tabular}{|c|c|c|c|}
\hline No. & Title & No. & Title \\
\hline 1 & Weak assessment of staffs' capacity & 18 & Inadequate training of the project managers and $\mathrm{QC}$ inspectors \\
\hline 2 & Failing to assess suppliers' capacity & 19 & Failing to conduct proper heat treatment on the part of suppliers \\
\hline 3 & Technical weakness of the contractors & 20 & $\begin{array}{l}\text { improper working environment for QC inspectors and project } \\
\text { managers and improper measurement environment }\end{array}$ \\
\hline 4 & Insufficient identified contractors & 21 & Ineffective supplier evaluation system \\
\hline 5 & Lack of technical feasibility study on the part of contractors & 22 & Incomplete quality control instructions \\
\hline 6 & Lack of capacity feasibility study on the part of contractors & 23 & Lack of QC inspectors evaluation system \\
\hline 7 & Geographical distance to the contractors & 24 & Lake of project managers evaluation system \\
\hline 8 & Not having suitable environment for accurate measurement & 25 & Inaccurate calibration system \\
\hline 9 & Difficulty in providing special control tools & 26 & $\begin{array}{l}\text { Not taking quality standards into consideration (requirements of } \\
\text { contracts) by the project managers and producers }\end{array}$ \\
\hline 10 & Lake of a base time & 27 & Lake of statistical quality control system \\
\hline 11 & Administrative bureaucracy (complexity of the process) & 28 & Improper packaging and transportation \\
\hline 12 & Poor contractor selection & 29 & $\begin{array}{l}\text { Failing to define the exact specifications of product, design and } \\
\text { preparation of technical documents }\end{array}$ \\
\hline 13 & Lack of documented process procedure & 30 & Low quality raw materials used by the suppliers \\
\hline 14 & Inadequate staff expertise & 31 & Poor performance of QC inspectors \\
\hline 15 & $\begin{array}{l}\text { Failing to provide technical maps and documents for the } \\
\text { contractors in time }\end{array}$ & 32 & Unmotivated QC inspectors \\
\hline 17 & $\begin{array}{l}\text { Quality control system inefficiency (units' interaction) } \\
\text { Evaluating staffs performance based on volume of the production } \\
\text { rather that quality of products }\end{array}$ & 33 & $\begin{array}{l}\text { Not considering waiting time for quality control in production } \\
\text { planning by project managers }\end{array}$ \\
\hline
\end{tabular}

\section{Improvement Phase}

In this phase, appropriate and effective solutions for the identified root causes in the previous phase are proposed, and then evaluated, selected and finally implemented. Overall, improvement phase can be divided to three main parts of identifying solutions, prioritizing solutions and executing them. Actually, Budget and time constraints and problem-solving capacity of the organization need to be taken into consideration. Thus, necessarily first the more important causes must be taken into account which are the Pareto analysis. By holding brain storm meetings and investigating possible solutions for each root, a list of solutions were obtained (table 8); it got clear that the main part of the solutions were common. Therefore, along with listing the mentioned solutions, they were prioritized in table 10. Following steps were taken in improvement phase:

1. Listing all possible solutions for the main identified roots

2. Refining and prioritizing the list of solutions based on determined criteria

3. Initial planning and appointing implementation teams

4. Activities and resources planning

5. Time scheduling (Gantt Chart preparation)
6. Assigning tasks to the teams and defining action plan

7. Training the teams

8. Implementing solutions (activities) by the teams

9. Results evaluation

10. Troubleshooting and supplementary measures

\section{Table 8}

The list of solutions

\begin{tabular}{cl}
\hline No. & Solution \\
\hline 1 & Revising suppliers' identifying, evaluating and choosing system \\
2 & Preparing instructions for inquiring basic price and basic delivery time \\
3 & Improving contracting process \\
\hline 4 & Establishing suppliers information database \\
5 & Improving QC procedures \\
6 & Improving evaluation system \\
\hline 7 & Developing the comprehensive project management system \\
\hline 9 & Designing operational information database for all activities \\
10 & Improving employees' motivation system \\
11 & Quality policy review \\
12 & Ranking quality experts \\
13 & Needs assessment and providing calibration system for inspection equipment \\
14 & providing jobs standards \\
15 & Codifying and executing training programs for the existing procedures \\
16 & Strategy reconsideration \\
\hline 17 & Standardization (localization) production technology \\
\hline
\end{tabular}


Table 9

Criteria for prioritizing the solutions

\begin{tabular}{cl}
\hline No. & Title \\
\hline A & The manager's priority \\
B & Feasibility of project at the present time \\
& \\
C & $\begin{array}{l}\text { Feasibility based on authorities and capabilities of } \\
\text { project team }\end{array}$ \\
D & Coordination with Six Sigma project \\
E & Possibility of developing methods in other modules \\
F & Profitability \\
& \\
G & Effectiveness \\
\hline
\end{tabular}

Each criteria is scored between 0 and 5
Table 10

\begin{tabular}{|c|c|}
\hline No. & Title \\
\hline 1 & Improving outsourcing process \\
\hline 2 & $\begin{array}{l}\text { Revising suppliers' identifying, evaluating } \\
\text { and choosing system }\end{array}$ \\
\hline 3 & Improving contracting format and process \\
\hline 4 & improving suppliers information database \\
\hline 5 & Improving QC procedures \\
\hline 6 & $\begin{array}{l}\text { Revising data flow and designing operational } \\
\text { information database }\end{array}$ \\
\hline 7 & Upgrading the existing suppliers \\
\hline 8 & $\begin{array}{l}\text { Developing the comprehensive project } \\
\text { management system }\end{array}$ \\
\hline
\end{tabular}

\section{Control Phase}

In this phase, improvement project team makes sure that the problem has been solved (removal or neutralization of the main roots), solutions have been executed and the new proposed procedures have been completely established. In other words, control phase is the monitoring and maintaining phase. The followings measures were taken in this phase:

Step 1: Supervise execution of the solutions and making feedbacks,

Step 2: Document the whole procedure of defining and implementing of the improvement project,

Step 3: Document the experiences and the findings,

Step 4: Document conducted solution as standard procedures,

Step 5: Re-caluclate the Sigma level (sigma level of the contracting sub-process 0.7; supply subprocess 1.9; delivery sub-process 1.4 ),

Step 6: Investigat and discussion for defining the next improvement project and targeted Sigma level.

\section{Conclusion}

In conclusion, the improvement project brought the firm, the employer, the executer, and the executive team valuable lessons, including:

- At the beginning and before initiating the project, there were many doubts on whether it is a correct approach to conduct the project using Six Sigma and DMAIC methodology, or by using simpler methods like the seven-step problem solving traditional approach, desired results would be achieved in a better, easier and faster way.

- Deeper investigations made it clear to the team that DMAIC methodology is a structured problem solving methodology with a meaningful and coherent classification, leading to the achievement to desired results and effective problem solving. On the other hand, using SixSigma tools and techniques, should be highly selective and proportional to the conditions of the problem.

- Commitment of senior managers to definition and implementation of an improvement project, taking the position of employer and delegation of authority to a competent and influential person as the project manager, are of necessities and prerequisites to meet the objectives of an improvement project. 
- It is necessary to make sure of the correct definition of any improvement project before execution.

- However, the logic of DMAIC methodology demands that project team reconsider definition phase upon any ambiguity in definition, even in measurement or analysis phases.

- Before applying different methods of problem solving, it is needed to apply various methods of problem finding to determine improvement opportunities correctly. Techniques such as SPC, periodical/annual evaluation, organizational troubleshooting such as BSC, EFQM are some proper techniques of problem finding.

- The project team definitely needs to take advantage of opinions and experiences of at least a well-experienced master black belt level consultant.

- To have better results in improvement projects, we can proceed to develop a motivation system (regulations) at the organizational level.

This project only considered the CTQ of delivery delay. First, it is possible to set goals for higher Sigma level for this CTQ, other improvement projects can be defined. Second, other important issues like quality, necessity of reducing non-conforming lots and reducing the prices can be taken into consideration to continue the outsourcing process improvement and to define the future improvement projects.

\section{References}

Basu, R., \& Wright, N. (2003). Quality Beyond Six Sigma. Butterworth-Heinemann.

Cheshmberah, M., Makui, A., Seyedhosseini, S., \& Najmi, A. (2011). A new fuzzy MCDA framework for make-or-buy decisions: A case study of aerospace industry. Management Science Letters, 1(3), 323-330.

Ho, Y. C., Chang, O. C., \& Wang, W. B. (2008). An empirical study of key success factors for Six Sigma Green Belt projects at an Asian MRO company. Journal of Air Transport Management, 14(5), 263-269.

Jennings, D. (1997). Strategic guidelines for outsourcing decisions. Strategic Change, 6(2), 85-96.

Karadbhuje, S. W., Deshpande, S. B., \& Gorde, M. S. (2012). Six sigma qualities in business. International Journal of Engineering and Innovative Technology, 1(4), 285-290.

Kremic, T., Tukel, O. I., \& Rom, W. O. (2006). Outsourcing decision support: a survey of benefits, risks, and decision factors. Supply Chain Management: an international journal, 11(6), 467-482.

Kumar, U. D., Nowicki, D., Ramírez-Márquez, J. E., \& Verma, D. (2008). On the optimal selection of process alternatives in a Six Sigma implementation. International Journal of Production Economics, 111(2), 456-467.

Kwak, Y. H., \& Anbari, F. T. (2006). Benefits, obstacles, and future of six sigma approach. Technovation, 26(5), 708-715.

Pyzdek, T. (2003). The six sigma project planner. A Step by Step Guide to Leading a Six Sigma Project Through DMAIC.

Schroeder, R. G., Linderman, K., Liedtke, C., \& Choo, A. S. (2008). Six Sigma: definition and underlying theory. Journal of operations Management, 26(4), 536-554. 